\title{
Pediatric Tumor Cells Express Erythropoietin and a Functional Erythropoietin Receptor that Promotes Angiogenesis and Tumor Cell Survival
}

\author{
Sandeep Batra, Natalya Perelman, Lori R. Luck, Hiroyuki Shimada, and \\ Punam Malik
}

Division of Hematology-Oncology (SB, NP, LRL, HS, PM), Childrens Hospital Los Angeles, and Departments of Pediatrics (SB, NP, LRL, HS, PM) and Pathology (HS, PM), Keck School of Medicine, University of Southern California, Los Angeles, California

SUMMARY: Erythropoietin was traditionally considered an erythroid-restricted cytokine, but recent evidence indicates a broader role for it in nonhematopoietic tissues, specifically in neural development. Pediatric solid tumors are mostly developmental in origin, and more than $50 \%$ of the solid tumors are neural in origin. We found erythropoietin receptor and erythropoietin expression in common pediatric tumor cells: neuroblastomas, Ewing's sarcoma family of tumors, pediatric brain tumors (medulloblastoma, astrocytoma, and ependymoma), Wilms tumors, rhabdomyosarcomas, and hepatoblastomas $(n=24)$, and in cell lines derived from some of these tumors $(n=25)$. Expression of erythropoietin in tumor cell lines was hypoxia-inducible. Addition of exogenous erythropoietin to tumor cell lines expressing erythropoietin receptor increased nuclear DNA binding activity of nuclear factor kappa B and increased the expression of the antiapoptotic genes $b c l-1, b c l-x L$, and $m c l-1$. Additionally, exogenous erythropoietin increased production and secretion of angiogenic growth factors, vascular endothelial growth factor, or placenta growth factor from the tumor cell lines, which promoted endothelial cell proliferation and chemotaxis. Erythropoietin receptor expression that promotes tumor cell survival and releases angiogenic growth factors in pediatric tumors has not been previously described. Therefore, a careful evaluation of the impact of erythropoietin is warranted in vivo, in xenograft models of pediatric tumors, followed by evaluation in pediatric patients with cancer. (Lab Invest 2003, 83:1477-1487).

$E$ rythropoietin (Epo) promotes survival, expansion, and differentiation of erythroid cells. Due to its red-cell restricted activity, it is widely used to treat anemia in several clinical settings: in end-stage renal disease, in cancer patients following cancer chemotherapy, and in preterm infants. The following findings suggest that effects of Epo may be broader than previously recognized: a) Epo and its cognate erythropoietin receptor (Epo-R) are expressed on various nonerythroid tissues (Juul, 2000); b) Epo has been found to promote survival of endothelial cells (Carlini et al, 1999) and neurons (Dillard et al, 2001; Juul, 2000; Juul et al, 1998; Nagai et al, 2001); c) Epo-R may play a role in normal embryonal brain development (Yu et al, 2002); and d) its expression is seen in neurons of hippocampus, cortex, and midbrain areas of the brain where it promotes survival in the presence of hypoxia (Digicaylioglu et al, 1995).

\section{DOI: 10.1097/01.LAB.0000090156.94795.48}

Received June 20, 2003.

Supported in part by grants from the Children's Cancer Research Fund (to P.M.) and the National Institutes of Health, HL-PO1-48484 (to P.M.). Address reprint requests to: Dr. Punam Malik, Childrens Hospital Los Angeles, Mailstop 54, 4650 Sunset Boulevard, Los Angeles, California 90027.E-mail:pmalik@chla.usc.edu
Tumor centers are quite hypoxic (Hansgen et al, 1997; Harris, 2002; Vaupel et al, 2001), and 55\% of pediatric solid tumors (neuroblastomas, brain tumors, Ewing's sarcoma family of tumors [ESFT], and retinoblastomas) are of neural origin (Linet et al, 1999). Epo has also been shown to be estrogeninducible and plays an angiogenic role in normal uterine endometrium and female reproductive tissues that are estrogen dependent (Yasuda et al, 1998). Recently, it was shown that tumors of adult reproductive tissues, breast, uterus, and ovaries co-express Epo and a functional Epo-R (Blancher et al, 2000; Yasuda et al, 2001). The Epo and Epo-R profile of pediatric tumors is unknown.

Epo has been shown to confer a proangiogenic phenotype to normal endothelial cells (Ribatti et al, 1999). Tumor cells produce angiogenic growth factors in response to hypoxia. Therefore, the vascular effects of Epo would be particularly relevant in tumor angiogenesis. In this study, we investigated whether Epo and Epo-R are expressed in common pediatric tumors and if Epo signaling was linked to the angiogenic and antiapoptotic pathways in tumor cells.

Pediatric tumors are mostly malignancies of undifferentiated cells of embryonal or fetal origin and inherently differ from adult malignancies in type, tissue of origin, and behavior. The Epo/Epo-R profile 
and the biological role of Epo-R expression in pediatric tumors are unknown.

\section{Results}

\section{Epo and Epo-R Expression in Primary Pediatric Tumor Cells}

We examined 24 primary tumor specimens of common pediatric tumors: neuroblastomas, brain tumors, ESFTs, rhabdomyosarcomas, Wilms tumors (WTs), and hepatoblastomas for expression of Epo or Epo-R (Table 1). Primary tumor tissue showed expression of Epo and Epo-R by RT-PCR analyses (representative tumors shown in Fig. 1A). Immunohistochemistry showed expression of Epo and Epo-R confined specifically to tumor cells, with minimal staining of surrounding tissues (Fig. 1B). Surrounding stromal tissue and endothelium within tumor samples served as built-in negative and positive controls, respectively (Fig. 1B). Fetal liver suspension and placenta were used as positive controls for expression of Epo and Epo-R, respectively, and fibroblasts were used as a negative control. Tumors were also stained with the second antibody alone, and appropriate isotype controls showed no staining. There was variation in expression in some tumor types, with different areas of the same tumor section showing variable intensity staining (Table 1). Tumors that stained intensely and uniformly for Epo were hepatoblastomas and WTs, followed by ESFT and rhabdomyosarcomas, while those showing highly intense staining for Epo-R were rhabdomyosarcomas, ESFTs, neuroblastomas, and brain tumors (Table 1).

\section{Epo-R Expression in Tumor Cell Lines}

Based on the above results, the Epo-R expression in tumor cell lines derived from pediatric solid tumors was studied to further analyze Epo-R signaling. The following cell lines $(n=24)$ expressed Epo-R as determined by RT-PCR, flow cytometry, or immunohistochemistry: neuroblastoma cell lines CHLA-90, SK-N-RA, KCNR, LHN, CHLA-15, CHLA-20, SK-N-FI, SK-N-BE-2, CHLA-171, SAN, LAN-5, LAN-6, and CHLA-134; ESFT cell lines CHP-100, A5838, SK-NMC, TC-106, TC-32, and TC-71; and medulloblas-

Table 1. Epo and Epo-R Expression in Primary Tumor Samples by RT-PCR and IH

\begin{tabular}{|c|c|c|c|c|}
\hline \multirow[b]{2}{*}{ Tumor } & \multicolumn{2}{|c|}{ Epo } & \multicolumn{2}{|c|}{ Epo-R } \\
\hline & $\mathrm{IH}^{a}$ & $\overline{\mathrm{RT}}-\mathrm{PCR}^{b}$ & $\mathrm{IH}^{a}$ & $\overline{\mathrm{RT}-\mathrm{PCR}^{b}}$ \\
\hline \multicolumn{5}{|l|}{ Renal } \\
\hline Wilms tumor (favorable histology) & $+(v)$ & + & $+(v)$ & + \\
\hline Wilms tumor (favorable histology) & + & + & + & + \\
\hline Wilms tumor (favorable histology) & + & + & $+(v)$ & + \\
\hline \multicolumn{5}{|l|}{ Liver } \\
\hline Embryonal hepatoblastoma & + & + & + & + \\
\hline Embryonal hepatoblastoma & + & + & $+(v)$ & + \\
\hline Fetal and embryonal hepatoblastoma & $+(v)$ & + & $+(v)$ & + \\
\hline Fetal and embryonal hepatoblastoma & + & + & + & + \\
\hline \multicolumn{5}{|l|}{ Muscle } \\
\hline Embryonal rhabdomyosarcoma & + & + & + & + \\
\hline Embryonal rhabdomyosarcoma & + & + & + & + \\
\hline Embryonal rhabdomyosarcoma & + & + & $+(v)$ & + \\
\hline Alveolar rhabdomyosarcoma & ND & - & ND & - \\
\hline \multicolumn{5}{|l|}{ Sympathetic nervous system } \\
\hline Neuroblastoma (favorable histology) & $+(\mathrm{v})$ & + & + & + \\
\hline Neuroblastoma (favorable histology) & + & + & + & + \\
\hline Neuroblastoma (favorable histology) & ND & + & ND & + \\
\hline Neuroblastoma (unfavorable histology) & - & - & $+(v)$ & + \\
\hline Neuroblastoma (unfavorable histology) & + & ND & + & + \\
\hline \multicolumn{5}{|l|}{ Brain } \\
\hline Anaplastic ependymoma & $+(\mathrm{v})$ & + & + & + \\
\hline Pilocytic astrocytoma & $+/-(\mathrm{v})$ & + & + & + \\
\hline Medulloblastoma & $+/-(\mathrm{v})$ & + & + & + \\
\hline Medulloblastoma & ND & + & ND & + \\
\hline Medulloblastoma & ND & + & ND & + \\
\hline \multicolumn{5}{|l|}{ Bone (neuro-ectodermal) } \\
\hline Ewing's sarcoma family of tumors & $+/-$ & + & ND & + \\
\hline Ewing's sarcoma family of tumors & $+(v)$ & + & + & + \\
\hline
\end{tabular}

Epo, erythropoietin; Epo-R, erythropoietin receptor; IH, immunohistochemistry.

${ }^{a} \mathrm{IH}$ was graded as follows: +, strong expression; +/-, weak expression; v, variable expression; and ND, not determined.

${ }^{b}$ RT-PCR was graded as follows: + , if amplified product was detected by ethidium bromide staining of gel and - , if it was not. 

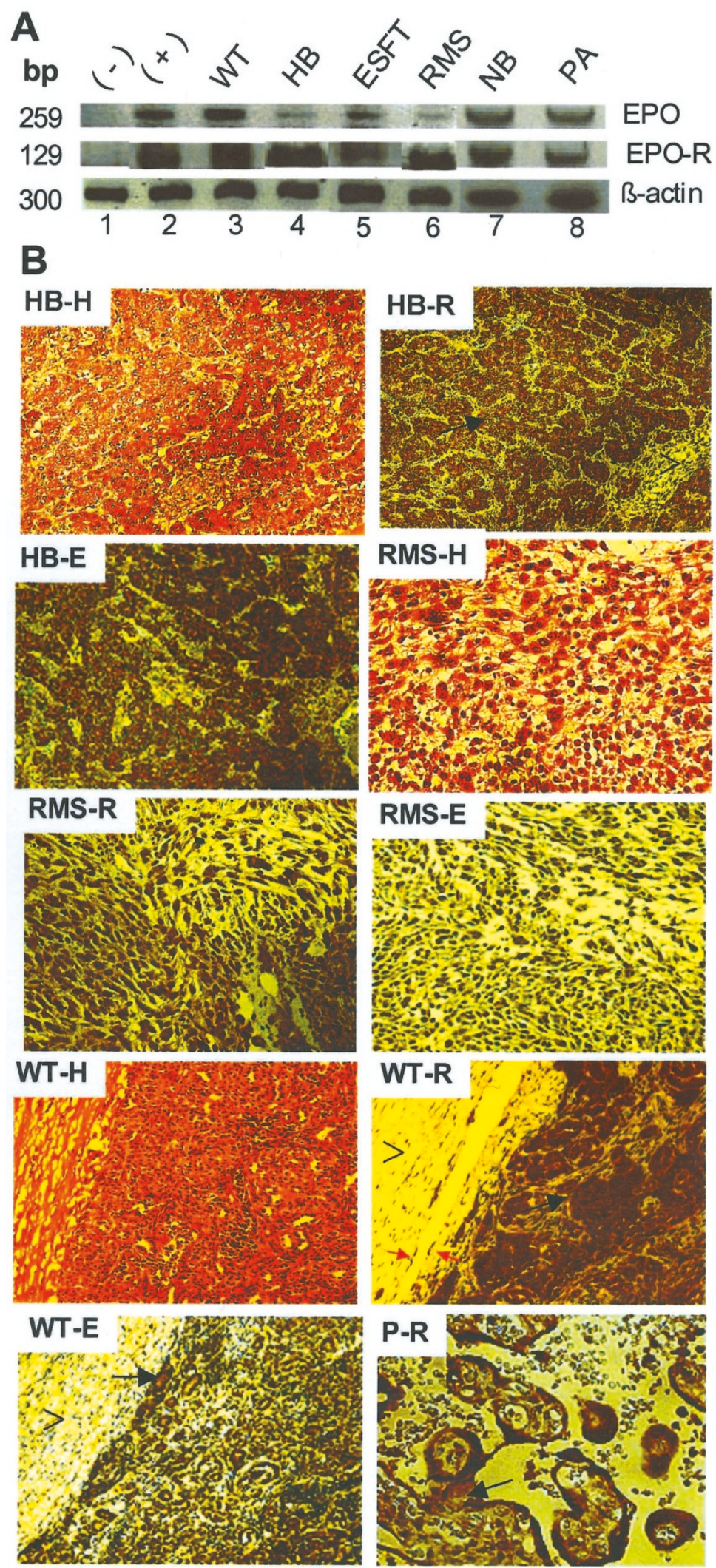

\section{Figure 1.}

Erythropoietin (Epo) and erythropoietin receptor $(E p o-R)$ expression in pediatric tumor biopsies. (A) RT-PCR analyses for Epo and Epo-R on freshly frozen representative tumor specimens (Lanes 3 to 8). Lane 1: Human fibroblasts (negative control for Epo and Epo-R). Lane 2: HepG2 (positive control for Epo) and placenta (positive control for Epo-R). (B) Immunohistochemistry. Representative paraffin-embedded sections of hepatoblastoma (HB), Wilms tumor (WT), rhabdomyosarcoma $(R M S)$ stained with hematoxylin and eosin $(H)$, Epo- $\mathrm{R}(R)$ and Epo $(E)(\times 100$ to $\times 200$ magnifications). Human placental tissue was used as a positive control for Epo-R $(P-R)$. The brown peroxidase reaction product of Epo and Epo-R in malignant cells is depicted with a black arrow. Endothelial cells (red arrow) and the surrounding fibroblastic stroma (arrowheads) served as built-in positive and negative controls, respectively. 
toma cell line DAOY. Adult tumor cell lines MCF-7 (breast cancer) and HT-29 (colon cancer), and T98G and A172 (gliomas) were also analyzed and expressed Epo-R. The MCF-7 cell line has been recently reported to express Epo-R (Acs et al, 2001). Figure 2 shows representative RT-PCR, FACS, and immunohistochemical analyses. The difference in degree of positivity by flow cytometry and immunohistochemistry can be explained by the difference in sensitivity of the two methods. Like primary tumors (Fig. 1B), Epo-R expression was variable even in cell lines (Fig. 2C). Epo-R expression has been reported to be cell-cycle dependent, with higher expression seen on cells in active cell division (Spivak et al, 1996), which may explain the variability in expression even in the clonal populations in cell lines.

\section{Epo Production in Tumor Cell Lines Is Induced with Hypoxia}

Although Epo-R as well as Epo expression were seen in primary tumors, most tumor cell lines expressed transcripts for Epo-R but not Epo when grown in ambient $\mathrm{O}_{2}$ concentrations (Fig. 3A). Epo expression is exquisitely hypoxia-inducible, and the $3^{\prime}$ untranslated region of the Epo gene contains hypoxiainducible factor response elements (Bunn et al, 1998; Stolze et al, 2002). The tumor microenvironment is hypoxic, with oxygen concentrations ranging from $2 \%$ to $3 \%$ (Hansgen et al, 1997). The promoters of most angiogenic growth factor genes contain hypoxiainducible factor response elements (Gleadle et al, 1995; Hansgen et al, 1997), and hypoxia in the tumors stimulates production of angiogenic growth factors. It was therefore conceivable that the primary tumor cells would express Epo in response to hypoxic tumor microenvironment. To examine this, an RT-PCR analysis for Epo was performed on ESFT cell lines SK$\mathrm{N}-\mathrm{MC}$ and TC71, the neuroblastoma cell line KCNR, and the colon carcinoma cell line HT-29 24 to 96 hours after they were cultured in ambient $\mathrm{O}_{2}$ concentrations (approximately $20 \% \mathrm{O}_{2}$ ) or in hypoxic conditions (2\% $\mathrm{O}_{2}$ ). All cell lines examined showed induction of Epo

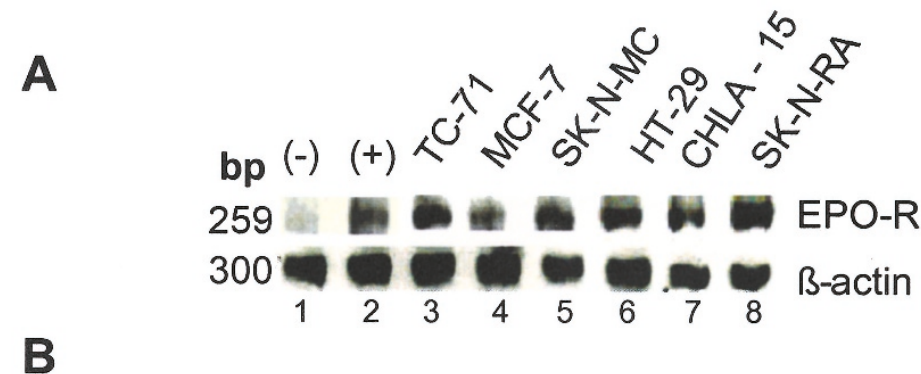

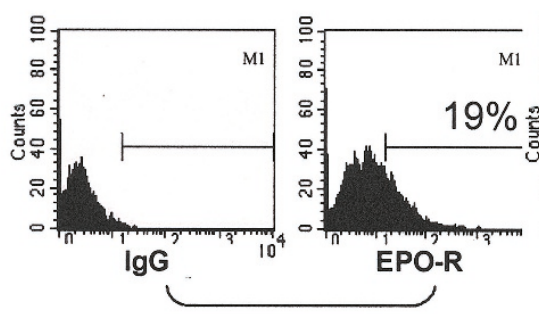

HT-29

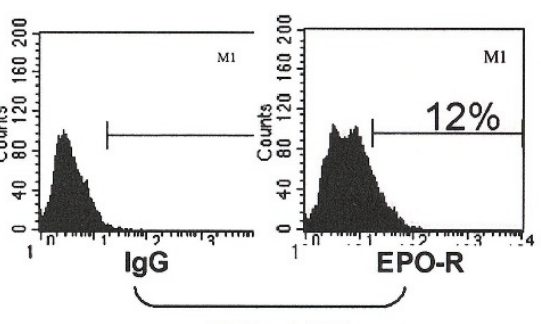

C

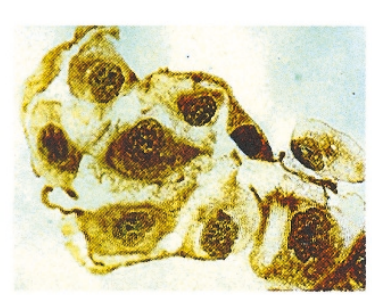

T98G

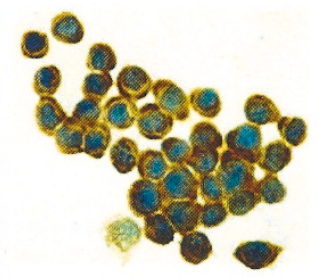

HT-29

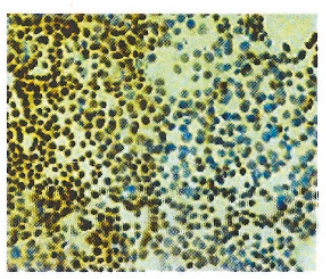

TC-71

Figure 2.

Erythropoietin receptor (Epo-R) expression in cell lines. (A) RT-PCR analyses for Epo-R on representative cell lines. Lane 1: Human fibroblasts (negative control). Lane 2: placenta (positive control). Lane 3: TC-71 (Ewing's sarcoma family of tumors [ESFT]), Lane 4: MCF-7 (breast cancer), Lane 5: SK-N-MC (ESFT), Lane 6: HT-29 (colon carcinoma), Lane 7: CHLA-15 (neuroblastoma), and Lane 8: SK-N-RA (neuroblastoma). (B) Flow cytometry for Epo-R on the HT-29 and TC-106 (ESFT) cell lines. The respective isotype controls are shown adjacent to the Epo-R histograms. $(C)$ Immunohistology for Epo-R on monolayers of adherent tumor cells grown on chamber slides: T98G (glioma; left panel, $\times 600$ magnification), HT-29; center panel, $\times 400$ magnification). TC-71 (right panel) cell line is shown at lower magnification $(\times 100)$ to illustrate the variable expression in different areas of the monolayer. 
A

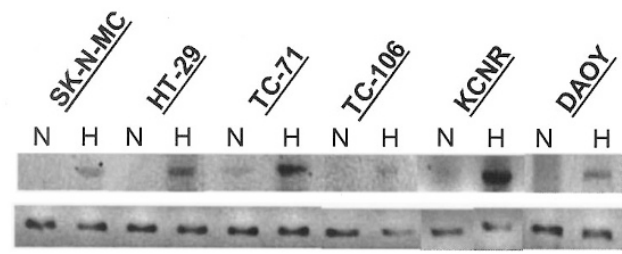

B
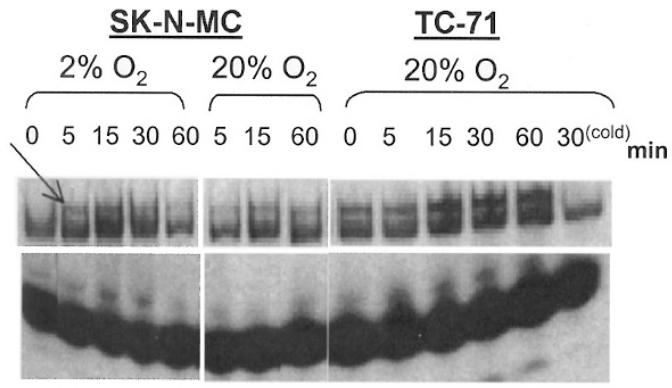

C

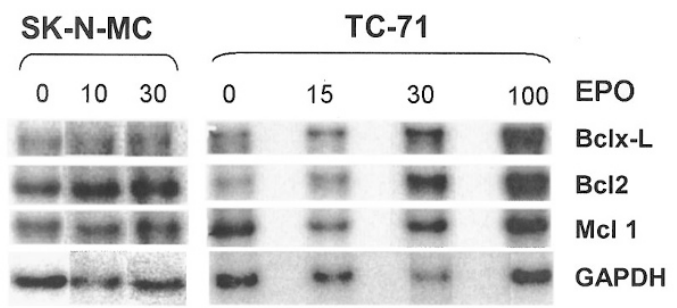

Figure 3.

Erythropoietin $(E p o)$ expression is induced by hypoxia, and epo upregulates antiapoptotic genes in tumor cell lines. (A) Semi-quantitative RT-PCR analysis for Epo in tumor cell lines grown in $20 \% \mathrm{O}_{2}$ (normoxia, $M$ ) or in $2 \% \mathrm{O}_{2}$ (hypoxia, $H$ ). (B) Electromobility shift assay showing that Epo increases nuclear DNA binding activity of nuclear factor kappa B (NF-kB) in the SK-N-MC and TC-71 Ewing's sarcoma family of tumor cells (top band, arrow) in normoxia and hypoxia. Addition of an unlabeled competitor or cold probe was added at 30 minutes (last lane), confirming the specificity of the probe to the top NFkB band. (C) RNase protection assay for antiapoptotic genes $b c l-x L$, $b c l-2$, and $m c l-1$ in TC-71 cells (right panel) and SK-N-MC cells (left panel) 24 hours after addition of exogenous Epo.

mRNA at $2 \% \mathrm{O}_{2}$ (Fig. 3A). Epo is antiapoptotic in erythroid cells. Up-regulation of Epo in tumor cells expressing Epo-R could therefore promote survival via an autocrine loop.

\section{Epo Induces an Antiapoptotic Response in Tumor Cells}

Epo promotes cell survival of erythroid progenitors and induces antiapoptotic genes (Gregory et al, 1999). We hypothesized that Epo similarly induced antiapoptotic gene expression in tumor cells. The neuro- protective response of Epo has been previously shown to be mediated by cross-talk between Janus kinase-2 (Jak 2, the immediate down-stream signaling molecule for Epo-R) and nuclear factor kappa B (NF $\kappa$ B) (Digicaylioglu and Lipton, 2001). NF $\kappa B$ induces an antiapoptotic response and increased $B C l-x L$ and $\mathrm{Bcl}-2$ gene expression in erythroid cells (Bittorf et al, 2001). To determine if similar signaling occurred in tumor cells, nuclear extracts from TC-71 ESFT and SK-N-MC neuroblastoma cells that had been exposed to Epo were isolated and analyzed for $\mathrm{NF}_{\kappa} \mathrm{B}$ DNA binding activity and for expression of antiapoptotic genes. Within 5 minutes after exposure to Epo, NF $\kappa$ B nuclear DNA binding activity was increased, with a peak response occurring at 30 to 60 minutes (Fig. 3B). There was a concomitant 2- to 9-fold increase in $\mathrm{bcl}-\mathrm{xL}, \mathrm{bcl}-2$, and mcl-1 mRNA expression in these cells when exposed to increasing concentration of Epo (Fig. 3C), as determined by densitometry analyses. These data show that Epo increases expression of antiapoptotic genes and may increase survival of pediatric tumors of neural origin in a manner analogous to its role in erythroid cells.

\section{Epo Induces an Angiogenic Response from Tumor Cell Lines}

The role of Epo in promoting an angiogenic response from endothelial cells has recently been demonstrated (Nitta et al, 1999; Ribatti et al, 1999). Tumors release a variety of angiogenic growth factors in response to hypoxia (Gleadle et al, 1995). We wanted to examine whether Epo induced expression of angiogenic growth factors directly in tumor cells. We therefore tested tumor cell lines that expressed both the Epo-R and angiogenic growth factors, vascular endothelial growth factor (VEGF), or placenta growth factor (PIGF). Exposure of HT-29 colon cancer cells or TC-32 ESFT cells to increasing amounts of exogenous Epo $(10$ and $30 \mathrm{U} / \mathrm{ml})$ resulted in a statistically significant increase in the amount of VEGF released into the medium (Table 2). The release of VEGF by TC-32 cells was dose dependent. Similar increases were observed with TC-106, TC-71 ESFT, and MCF-7 breast cancer cells, although the differences were not statistically significant (data not shown).

We next investigated whether the TC-106, SK-NMC, TC-71, and HT-29 cells expressed other angiogenic growth factors, such as PIGF. A Northern blot analysis on TC-106, TC-71, and SK-N-MC ESFT cells and HT-29 colon cancer cells demonstrated a dose-

Table 2. Addition of Epo causes VEGF ${ }^{a}$ release from HT-29 and TC-32 tumor cells

\begin{tabular}{lcccc}
\hline Cell line & Time after Epo & Control & Epo $(10 \mathrm{U} / \mathrm{ml})^{b}$ & Epo $(30 \mathrm{U} / \mathrm{ml})^{b}$ \\
\hline HT-29 & 4 hours & $491 \pm 75.0$ & $609 \pm 9.3(p=0.04)$ & $592 \pm 62(p=0.05)$ \\
HT-29 & 24 hours & $1830 \pm 220$ & $2836 \pm 45(p=0.004)$ & $3007 \pm 62(p=0.005)$ \\
TC-32 & 24 hours & $240.4 \pm 7.6$ & $340.4 \pm 20.6(p=0.05)$ & $917.1 \pm 3.0(p=0.003)$ \\
\hline
\end{tabular}

Epo, erythropoietin; VEGF, vascular endothelial growth factor.

${ }^{a}$ VEGF $(\mathrm{pg} / \mathrm{ml})$ in medium $\left(2 \times 10^{6} \mathrm{celll} / \mathrm{well}\right)$

${ }^{b} p$ Values are based on comparisons with control using Student's $t$ test. 
dependent increase in PIGF mRNA transcripts in these tumor cells when exposed to Epo (Fig. 4A). HT-29 cells that had previously shown release of VEGF upon Epo stimulation (Table 2) also appeared to increase PIGF expression in response to Epo. All of the tumor cell lines tested responded to Epo by increasing the production and release of angiogenic growth factors VEGF and/or PIGF. Epo is known to cause VEGF release from endothelial cells (Nitta et al, 1999). We show here that Epo can stimulate angiogenic growth factor release directly from tumor cells.

The VEGF gene promoter contains hypoxiainducible factor 1 response element, which has been previously shown to mediate increase in VEGF production under hypoxia (Fukuda et al, 2002; Semenza, 2002; Zhu and Bunn, 2001). The PIGF promoter, on the other hand, has nine consensus sequences for metal transcription factor-1 (MTF-1) response elements (Green et al, 2001). Addition of Epo to the SK-N-MC tumor cell line expressing Epo-R resulted in increased MTF-1 DNA binding activity in the nucleus (Perelman et al, 2003), suggesting this may be the mechanism of Epo-mediated PIGF expression.

\section{Epo Induces Endothelial Cell Proliferation and Chemotaxis from Tumor Cell Lines}

To examine whether Epo mediates stimulation of a functional angiogenic response, conditioned medium was harvested from brain tumor cell lines 16 hours after exposure to Epo, and microvascular endothelial cells were exposed to it to analyze endothelial proliferation and chemotaxis. Conditioned medium from a glioma cell line (T98G) was used to study the chemotaxis of human brain micro-vascular endothelial cells (HBMVECs). There was significantly increased endothelial cell chemotaxis toward Epo-conditioned medium compared with control medium collected from untreated cells. Figure 4B section (i) shows representative membranes, and section (ii) depicts the cumulative results of the number of transmigrated cells $(n=$ $3, p<0.03$ ). Epo-conditioned medium from an early passage medulloblastoma cell line (DAOY cells) also augmented endothelial cell proliferation, as determined by increased ${ }^{3} \mathrm{H}$-thymidine incorporation into dividing cells (Fig. 4C). $30 \mathrm{U}$ Epo increased ${ }^{3} \mathrm{H}$ thymidine uptake in HBMVECs (15222 $\pm 3451 \mathrm{cpm})$ compared with control conditioned media (3299 \pm $1017 \mathrm{cpm}, p<0.003$ ) and exceeded the hypoxiainduced endothelial proliferative response.

\section{Discussion}

We analyzed tumor cell lines and primary tumor cells for Epo and Epo-R expression at the RNA and protein level. Most of the common pediatric tumors expressed Epo and a functional Epo-R, which promoted cell survival genes and increased release of angiogenic growth factors from tumor cells.

Although Epo is produced by adult kidney in response to hypoxia and its cognate Epo-R is expressed on erythroid cells where it plays a central role in

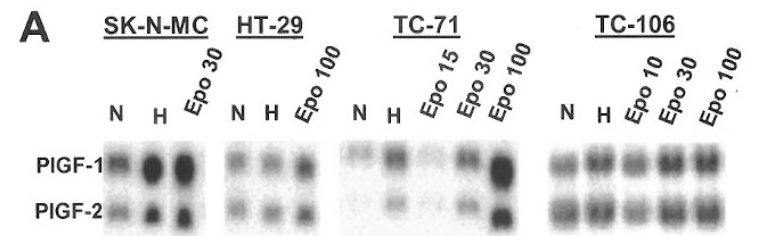

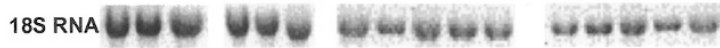
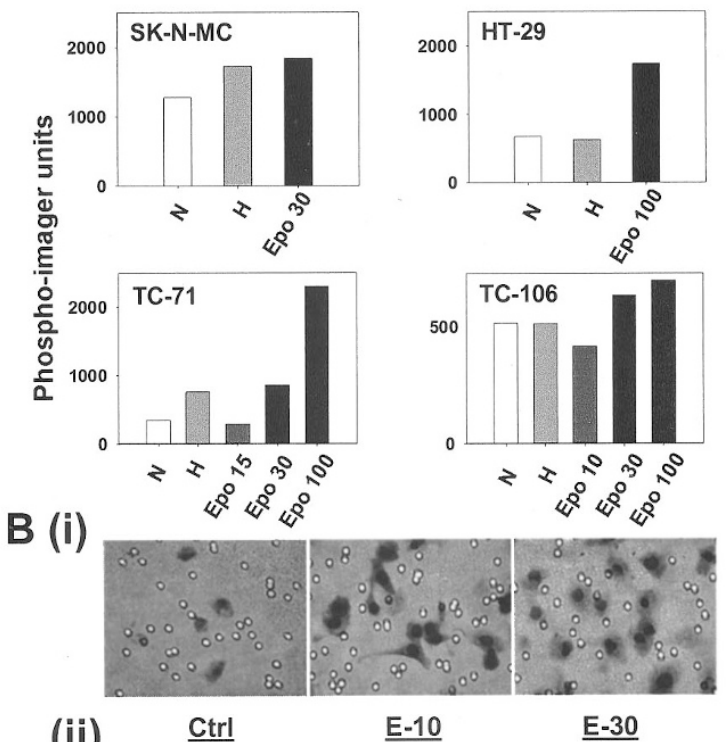

(ii)

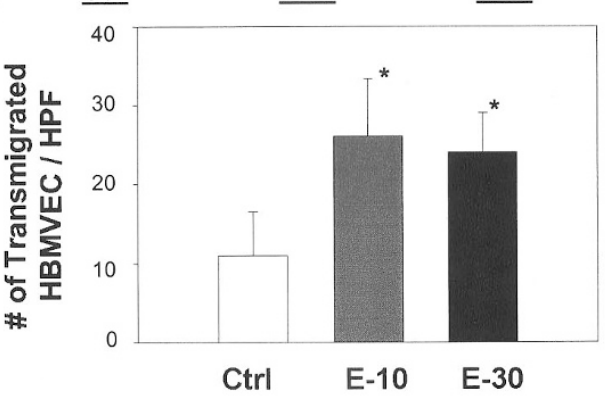

C

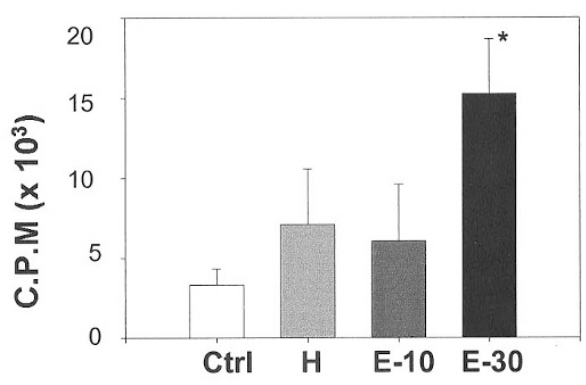

Figure 4.

Exogenous erythropoietin (Epo) promotes an angiogenic response from tumor cells. (A) Northern blot analysis for placenta growth factor (PIGF) in the SK-N-MC, TC-71, and TC-106 Ewing's sarcoma family of tumor cells and HT-29 colon cancer cells treated with different concentrations of Epo under normoxia $\left(\mathrm{N}, 20 \% \mathrm{O}_{2}\right)$ or hypoxia $\left(\mathrm{H}, 2 \% \mathrm{O}_{2}\right)$. The two bands represent PIGF-1 and PIGF-2 isoforms. The top band (PIGF-1) was quantified using a phosphoimager, and analyses are represented in the panels beneath the Northern blot. (B) Epo-conditioned medium (CM) from T98G glioma cells induces human brain micro-vascular endothelial cell (HBMVEC) chemotaxis. (i) A representative transwell membrane showing migrated HBMVECs toward Epo CM. E-10 and E-30 are CM after obtained after 16 hours of $10 \mathrm{U} / \mathrm{ml}$ and $30 \mathrm{U} / \mathrm{ml}$ of Epo treatment of glioma cells, respectively. (ii) The cumulative results representing the mean migrated HBMVECs/field $(n=3, p$ $<0.05$ ). (C) Epo CM from the DAOY medulloblastoma cells increased HBMVEC proliferation as measured by ${ }^{3} \mathrm{H}$ thymidine uptake $(n=3, p<0.05)$. 
erythropoiesis, recent studies have shown Epo and Epo-R expression in the fetal nervous system (Juul et al, 1998, 1999; Liu et al, 1994) and its importance in brain homeostasis later in life (Dillard et al, 2001; Yu et al, 2002). Nearly $55 \%$ of pediatric solid tumors (neuroblastomas, ESFT, brain tumors, and retinoblastomas) are of neural origin (Linet et al, 1999). Therefore, it would not be surprising that malignancies derived from neural tissues expressed Epo-R. There are reports of Epo promoting proliferation and preventing differentiation of myoblasts (Ogilvie et al, 2000), suggesting that Epo/Epo-R may also play a biological role in rhabdomyosarcomas. Besides pediatric neural and muscle tumors, we also found Epo-R and Epo expression in WTs and hepatoblastomas. The intense staining of Epo in WTs is consistent with previously published reports (Murphy et al, 1976; Thurman et al, 1966). We additionally found a high level of Epo-R expression in WTs. Hepatoblastomas are malignancies of embryonal/fetal liver origin, and interestingly, liver is the primary site for erythropoiesis and Epo production in the fetus. Epo, but not Epo-R expression, has been previously shown in hepatomas and hepatocellular carcinomas (Goldberg et al, 1987; Sakisaka et al, 1993).

Studies on the functional significance of the nonerythroid Epo show that Epo is produced by astrocytes and neurons (Yu et al, 2002) in response to hypoxia (Marti et al, 1996; Nagai et al, 2001). Hypoxia is a characteristic property of enlarging solid tumors, resulting from an imbalance between the supply and consumption of oxygen (Hansgen et al, 1997). The oxygenation status of tumors is greatly affected by the hemoglobin level (Vaupel et al, 2001). Hypoxia is intensified in anemic patients and especially in tumors with low perfusion rates. Studies show that hypoxia and anemia make solid tumors resistant to sparsely ionizing radiation and some forms of chemotherapy, an effect that can be at least partially prevented or overcome by correction of anemia (Vaupel et al, 2001). Epo expression is hypoxia-inducible in neuroblastoma and ESFT tumor cell lines. Therefore, the local production of Epo by the same tumor cells that also express Epo-R could promote tumor cell survival in a relatively hypoxic tumor core.

We found that Epo played a similar role in tumor cells as has been shown in erythroid cells: Epo increases the nuclear DNA binding activity of $\mathrm{NF}_{\kappa} \mathrm{B}$, a transcriptional factor known to increase the transcription of antiapoptotic genes (Bittorf et al, 2001). Epo signaling has been previously shown to exert an antiapoptotic effect in neurons through activation of NF $-\kappa \mathrm{B}$ (Bittorf et al, 2001; Digicaylioglu and Lipton, 2001). It is conceivable that tumor hypoxia could cause a secondary increase in Epo concentrations locally within tumor cells, triggering survival pathways.

Recent evidence shows that Epo confers a proangiogenic phenotype to endothelial cells and induces a strong angiogenic response in vivo in chick chorioallantoic membranes (Ribatti et al, 1999). Epo has also been shown to cause release of VEGF, a potent angiogenic growth factor from endothelial cells. We show that tumor cells can directly release increasing amounts of VEGF and PIGF in response to Epo, the latter effect associated with nuclear translocation of MTF-1 (Perelman et al, 2003). Angiogenesis is the primary requirement for tumor growth and an important target in therapeutic trials using antiangiogenic therapies. We propose that expression of a functional Epo-R by tumor cells is one of the mechanisms by which tumor cells survive and initiate angiogenesis in a hypoxic microenvironment. Endogenous production of Epo from tumor cells could further augment tumor angiogenesis from surrounding tumor endothelium in a paracrine manner.

Epo could thus play a putative oncogenic role in these tumors. Recent studies on adult malignancies uterine cancer (Yasuda et al, 2001) and breast cancer (Blancher et al, 2000) have shown that these tumors express Epo-R. Normal female reproductive organs such as the uterine endometrium express estrogen receptor and respond to Epo in an estrogeninducible manner (Yasuda et al, 1998). Recently, it was shown that malignant breast tumors have a higher level of Epo expression than benign tumors (Acs et al, 2002). Moreover, deprivation of Epo signaling in malignant uterine tumors and breast cancer induces cell death of tumor and capillary endothelial cells in tumor xenografts in vivo (Arcasoy et al, 2002; Yasuda et al, 2001). Although adult tumors are mainly malignancies of more differentiated cells, pediatric tumors are mainly malignancies of developmental origin (embryonal and fetal). Epo and Epo-R play a role in embryonic development, which may be relevant to the fetal and embryonic origin of common pediatric tumors. It would therefore be important to study the functional significance of abrogating Epo signaling in vivo xenograft models of pediatric tumors.

Epo is widely used to treat therapy-related anemia in adults with cancer and is currently in clinical trials in pediatric tumors. Because the tumor cells that also express the Epo-R produce Epo endogenously, Epo could initiate signaling through an autocrine loop in tumor cells. Also, circulating Epo concentrations may underestimate the local concentration seen by the tumor cells. Therefore, exogenous Epo administration for treating cancer-related anemia may not be of any harmful consequence, as plasma Epo concentrations may not be relevant in tumors that produce Epo endogenously. Moreover, unlike hematopoietic tissues that are responsive to relatively lower concentrations of Epo, higher concentrations of Epo, which are usually achievable only by local production, may be required by tumor cells.

While this paper was undergoing preparation, several studies were published reporting: a) the role of Epo in preventing retinal hypoxia-reperfusion injury in retinal neurons and retinal oxidative damage (Grimm et al, 2002; Junk et al, 2002), b) the role of Epo in promoting neuronal repair after spinal cord injuries (Gorio et al, 2002), c) Epo expression in breast cancer cells that is hypoxia inducible (Acs et al, 2002), d) abrogation of breast cancer in xenograft models with blocking of Epo signaling (Arcasoy et al, 2002), e) 
hypoxia-inducible expression of Epo in three neuroblastoma cell lines (Stolze et al, 2002), f) a potential role of Epo in inducing angiogenesis in myelodysplastic syndrome (Ribatti, 2002), g) effects of Epo on glial cell development, and h) oligodendrocyte maturation and astrocyte proliferation (Sugawa et al, 2002). All of these studies underscore the importance of Epo signaling in nonerythroid cells, especially in cells of neuronal origin and in some adult malignancies.

None of these studies have addressed the fact that that Epo promotes release of angiogenic growth factors directly from tumor cells and has an antiapoptotic role in pediatric tumor cell lines. Therefore, our findings showing a functional Epo-R expression in pediatric tumors warrant a careful evaluation of the role of Epo in tumor angiogenesis and tumor survival in vivo.

Additionally, if blocking Epo signaling in these tumors causes tumor regression in vivo, as shown in xenograft models of breast and uterine cancer, Epo antagonists (with transfusion support) could be potentially used in conjunction with antiangiogenic agents or chemotherapy treatment protocols. If these results are confirmed in xenograft models of pediatric solid tumors, the clinical trials re-evaluating use of Epo for anemia related to cancer therapy or evaluating blockade of Epo-R signaling in tumors as a therapeutic modality are warranted (Suzuki et al, 2002).

\section{Materials and Methods}

\section{Cell Culture and Treatments}

ESFT, neuroblastoma, and medulloblastoma cell lines were kindly provided by Drs. C. P. Reynolds and W. E. Laug (Childrens Hospital Los Angeles). Other cell lines were purchased from American Type Culture Collection (Rockville, Maryland) and maintained in RPMI, $10 \%$ heat-inactivated fetal bovine serum (FBS) (BioWhittaker, Walkersville, Maryland). Cell lines derived in the laboratory of Dr. C. Patrick Reynolds were maintained in IMDM with 20\% FBS. HBMVECs were a kind gift of Dr. W. E. Laug. The HBMVECs were cultured in M199 medium supplemented with $100 \mu \mathrm{g} / \mathrm{ml}$ heparin, $30 \mu \mathrm{g} / \mathrm{ml}$ endothelial cell growth factor, and 10\% FBS. Tumor cells and HBMVECs were detached using cell dissociation buffer (Sigma, Rockville, Maryland). For treatments, cells were plated overnight in serum-free X-Vivo15 medium (BioWhittaker) to prevent a serumstarvation response and reduce interference from cytokines that may be present in FBS. Hypoxic treatment of cells was performed either in an enclosed chamber (Billups-Rothenberg Inc., Del Mar, California) flushed with $2 \% \mathrm{O}_{2}$ (corresponds to $\mathrm{pO}_{2}$ of approximately $15 \mathrm{mmHg}$ ), $5 \% \mathrm{CO}_{2}$, and $93 \%$ nitrogen gas mixture or in a water jacket incubator with a two-stage gas regulator Model 1184 type A/B3 incubator (Forma Scientific, Marietta, Ohio).

\section{RNA Analyses}

RNA was extracted using the RNA-Stat kit (Tel-Test, Friendswood, Texas). For RT-PCR, $1 \mu \mathrm{g}$ of total RNA per sample was reverse-transcribed to cDNA using the Su- perscript RT-PCR kit (PE-Applied Biosystems, Foster City, California). The cDNA was amplified by PCR $94^{\circ} \mathrm{C}$ $\times 1$ minute, $60^{\circ} \mathrm{C}$ annealing $\times 1$ minute, $72^{\circ} \mathrm{C} \times 1$ minute $\times 40$ using the following primer pairs: Epo-R F707 5'GAGTAGGACTG-3', R969 5'-CAGCAGGGGGCCCTCATCAT-3', Epo F149 5'-ATGTGGATAAAGCCGTCAGTG-3', R405 5'-GCAGTGATTGTTCGGAGTGG-3', human $\beta$-actin F506 5'-ACTGGCATCGTGATGGACTC3', and F803 5'-TCAGGCAGCTCGTAGCTCTT-3'. Epo and Epo-R primers span an intron and, therefore, show distinct bands for cDNA and genomic DNA. RNA was subjected to Northern blot analyses, as previously described (Malik et al, 1995). RNase protection assays were performed using the antisense DNA templates from Pharmingen (San Diego, California) and the Riboquant In Vitro Transcription Kit as previously described (MoreauGaudry et al, 2001). Briefly, ${ }^{32} \mathrm{P}$-labeled antisense RNA was transcribed from bcl-2, bcl-xL, mcl-1, and GAPDH DNA templates and hybridized to cellular RNA. After RNase digestion, protected fragments were resolved on a $6.5 \%$ polyacrylamide gel. Bands were quantified using densitometry on the Eagle Eye II still video system using the Eagle Sight software version 3.22 (Stratagene, Cedar Creek, Texas) or on a Phosphoimager (Bio-Rad, Hercules, California).

\section{Immunohistochemistry}

Immunohistochemical analysis was performed on paraffin-embedded tissue retrieved from the surgical pathology files of Childrens Hospital Los Angeles. The protocol used was approved by the Committee on Clinical Investigation (the Institutional Review Board) and followed conditions previously described by Acs et al (2001). Four- $\mu \mathrm{M}$-thick sections were cut from each block using DAKO Biotin blocking system (Carpenteria, California) and were treated with 3\% hydrogen peroxide. Sections were incubated with antibodies against Epo (goat polyclonal, Santa Cruz Biotechnology, Santa Cruz, California) or Epo-R (rabbit polyclonal, Santa Cruz Biotechnology), washed, and then incubated with biotinylated goat antirabbit Ig G secondary antibody (DAKO) for Epo or biotinylated goat antirabbit Ig G secondary antibody (Santa Cruz) for Epo-R. The sections were stained with horseradish peroxidase-conjugated streptavidin (Streptavidin HP detection system, Research Genetics, Huntsville, Alabama), developed with diaminobenzidine chromogen, and counterstained with hematoxylin. Slides of human fetal liver tissue and placenta were used as positive controls for Epo and Epo-R, respectively. A slide from each tumor stained without primary antibody was used as negative control.

\section{ELISA}

VEGF was quantified using the Quantikine Immunoplate VEGF ELISA kit (R\&D Systems) as per manufacturer's instructions. 


\section{Electrophoretic Mobility Shift Assays}

Nuclear extracts were prepared from Epo-treated cells and untreated control cells (Lu et al, 2000). Cells were lysed in $50 \mathrm{~mm} \mathrm{KCl,} 25$ mm HEPES, pH 8.0, 100 mм DTT, $1 \%$ NP-40 and protease inhibitor cocktail (Sigma) for 5 minutes on ice. The nuclei were washed, pelleted, and resuspended in extraction buffer $(500 \mathrm{~mm} \mathrm{KCl,} 25 \mathrm{~mm}$ HEPES, pH 8.0, 100 mM DTT, 10\% glycerol, and protease inhibitor cocktail) at $4^{\circ} \mathrm{C}$ for 30 minutes with constant shaking. Nuclear extracts were incubated in 25 $\mu$ l 10 mм Tris-HCl, pH 7.6, 0.1 mм EDTA, 5 mм MgCl, 1 mM DTT, $10 \%$ glycerol, $40 \mathrm{mg} / \mathrm{ml}$ poly (dl-dC), and 50 $\mathrm{mM} \mathrm{KCl}$ and ${ }^{32} \mathrm{P}$-labeled oligonucleotide probe carrying $\mathrm{NF} \kappa \mathrm{B}$ binding sites at room temperature for the indicated times. A 100-fold molar excess of unlabeled oligonucleotides were used as a competitor. The reaction mixtures were resolved on $4 \%$ acrylamide gel with $0.5 \%$ TBE buffer. The sequence of the DNA probes used for the electrophoretic mobility shift assay was $\mathrm{NF} \kappa \mathrm{B}$ 5'-GCGCCTTCCCGGAAACTCCCGCCTGGCC-3'.

\section{Endothelial Cell Migration and Proliferation}

Migration assay was performed with minor modification of a previously described technique (Shimonaka and Yamaguchi, 1994) in a collagen-treated Boyden chemotactic apparatus (Costar Transwell Migration Plate \#3421). Epo-conditioned medium derived from tumor cells exposed to 16 hours of Epo was placed in the lower chamber. In the upper chamber, 50,000 HBMVECs in $100 \mu \mathrm{l}$ of RPMl were placed and incubated for 16 hours. Filters were removed, fixed with methanol, and stained with Diff-Quick (Baxter, Miami, Florida). The number of migrated cells on the lower surface of the filter was counted in nine randomly chosen fields and averaged. Experiments were performed in triplicate. Proliferation was measured using ${ }^{3} \mathrm{H}$-thymidine uptake of endothelial cells grown in 24-hour conditioned medium collected from Epotreated and untreated cells.

\section{Flow Cytometry Analyses}

Fluorescence-activated cell sorter analyses for Epo-R were performed on a FACS-Calibur Flow Cytometer (Beckton Dickinson, San Jose, California). Tumor cells were stained with rabbit antibody to human Epo-R (rabbit polyclonal, C-20 $1 \mu \mathrm{g}$; Santa Cruz Biotechnology) for 20 minutes after a 10-minute incubation with human Ig $\mathrm{G}$, to block nonspecific binding. The cells were then resuspended in PBS, spun at $800 \times g$ and pellet resuspended in $100 \mu \mathrm{l}$ PBS and stained with a secondary goat antirabbit FITC antibody. Control cells were either stained with rabbit Ig G or with secondary antibody alone. Cells were washed again in PBS and and fixed with $2 \%$ paraformaldehyde.

\section{Acknowledgements}

We would like to thank Dr. C. P. Reynolds for providing us the tumor cell lines or RNA from them, derived in his laboratory; Dr. W. E. Laug for providing us the HBMVECs, some of the tumor cell lines, and for assisting with the transmigration assays; Dr. Vijay $\mathrm{K}$. Kalra for assistance with electromobility shift assays; and Drs. Siegel, Laug, Kalra, Kohn, and ErdreichEpstein for critically reviewing the manuscript and providing helpful suggestions. We are thankful to the Childrens Cancer Research Fund for their ongoing support. Certain intellectual property rights pertaining to the contents of this paper may be retained by the Childrens Hospital Los Angeles.

\section{References}

Acs G, Acs P, Beckwith SM, Pitts RL, Clements E, Wong K, and Verma A (2001). Erythropoietin and erythropoietin receptor expression in human cancer. Cancer Res 61:3561-3565.

Acs G, Zhang PJ, Rebbeck TR, Acs P, and Verma A (2002). Immunohistochemical expression of erythropoietin and erythropoietin receptor in breast carcinoma. Cancer 95:969981.

Arcasoy MO, Amin K, Karayal AF, Chou SC, Raleigh JA, Varia MA, and Haroon ZA (2002). Functional significance of erythropoietin receptor expression in breast cancer. Lab Invest 82:911-918.

Bittorf T, Buchse T, Sasse T, Jaster R, and Brock J (2001). Activation of the transcription factor NF-kappaB by the erythropoietin receptor: Structural requirements and biological significance. Cell Signal 13:673-681.

Blancher C, Moore JW, Talks KL, Houlbrook S, and Harris AL (2000). Relationship of hypoxia-inducible factor (HIF)-1alpha and HIF-2alpha expression to vascular endothelial growth factor induction and hypoxia survival in human breast cancer cell lines. Cancer Res 60:7106-7113.

Bunn HF, Gu J, Huang LE, Park JW, and Zhu H (1998). Erythropoietin: A model system for studying oxygendependent gene regulation. J Exp Biol 201:1197-1201.

Carlini RG, Alonzo EJ, Dominguez J, Blanca I, Weisinger JR, Rothstein M, and Bellorin-Font E (1999). Effect of recombinant human erythropoietin on endothelial cell apoptosis. Kidney Int 55:546-553.

Digicaylioglu M and Lipton SA (2001). Erythropoietinmediated neuroprotection involves cross-talk between Jak2 and NF-kappaB signalling cascades. Nature 412:641-647.

Digicaylioglu M, Bichet S, Marti HH, Wenger RH, Rivas LA, Bauer C, and Gassmann M (1995). Localization of specific erythropoietin binding sites in defined areas of the mouse brain. Proc Natl Acad Sci USA 92:3717-3720.

Dillard DG, Venkatraman G, Cohen C, Delgaudio J, Gal AA, and Mattox DE (2001). Immunolocalization of erythropoietin and erythropoietin receptor in vestibular schwannoma. Acta Otolaryngol 121:149-152.

Fukuda R, Hirota K, Fan F, Jung YD, Ellis LM, and Semenza GL (2002). IGF-1 induces HIF-1-mediated VEGF expression that is dependent on MAP kinase and PI-3-kinase signaling in colon cancer cells. J Biol Chem 277:38205-38211.

Gleadle JM, Ebert BL, Firth JD, and Ratcliffe PJ (1995). Regulation of angiogenic growth factor expression by hypoxia, transition metals, and chelating agents. Am J Physiol 268:C1362-C1368.

Goldberg MA, Glass GA, Cunningham JM, and Bunn HF (1987). The regulated expression of erythropoietin by two 
human hepatoma cell lines. Proc Natl Acad Sci USA 84: 7972-7976.

Gorio A, Gokmen N, Erbayraktar S, Yilmaz O, Madaschi L, Cichetti C, Di Giulio AM, Vardar E, Cerami A, and Brines M (2002). Recombinant human erythropoietin counteracts secondary injury and markedly enhances neurological recovery from experimental spinal cord trauma. Proc Natl Acad Sci USA 99:9450-9455.

Green CJ, Lichtlen P, Huynh NT, Yanovsky M, Laderoute KR, Schaffner W, and Murphy BJ (2001). Placenta growth factor gene expression is induced by hypoxia in fibroblasts: A central role for metal transcription factor-1. Cancer Res 61:2696-2703.

Gregory T, Yu C, Ma A, Orkin SH, Blobel GA, and Weiss MJ (1999). GATA-1 and erythropoietin cooperate to promote erythroid cell survival by regulating bcl-xL expression. Blood 94:87-96.

Grimm C, Wenzel A, Groszer M, Mayser H, Seeliger M, Samardzija M, Bauer C, Gassmann M, and Reme CE (2002). HIF-1-induced erythropoietin in the hypoxic retina protects against light-induced retinal degeneration. Nat Med 8:718724.

Hansgen G, Hintner I, Krause V, Wohlrab W, and Dunst J (1997). Intratumor pO2, S-phase fraction and p53 status in cervix carcinomas. Strahlenther Onkol 173:385-387.

Harris AL (2002). Hypoxia: A key regulatory factor in tumour growth. Nat Rev Cancer 2:38-47.

Junk AK, Mammis A, Savitz SI, Singh M, Roth S, Malhotra S, Rosenbaum PS, Cerami A, Brines M, and Rosenbaum DM (2002). Erythropoietin administration protects retinal neurons from acute ischemia-reperfusion injury. Proc Natl Acad Sci USA 99:10659-10664.

Juul SE (2000). Nonerythropoietic roles of erythropoietin in the fetus and neonate. Clin Perinatol 27:527-541.

Juul SE, Yachnis AT, and Christensen RD (1998). Tissue distribution of erythropoietin and erythropoietin receptor in the developing human fetus. Early Hum Dev 52:235-249.

Juul SE, Yachnis AT, Rojiani AM, and Christensen RD (1999). Immunohistochemical localization of erythropoietin and its receptor in the developing human brain. Pediatr Dev Pathol $2: 148-158$.

Linet MS, Ries LA, Smith MA, Tarone RE, and Devesa SS (1999). Cancer surveillance series: Recent trends in childhood cancer incidence and mortality in the United States. J Natl Cancer Inst 91:1051-1058.

Liu ZY, Chin K, and Noguchi CT (1994). Tissue specific expression of human erythropoietin receptor in transgenic mice. Dev Biol 166:159-169.

Lu R, Au WC, Yeow WS, Hageman N, and Pitha PM (2000). Regulation of the promoter activity of interferon regulatory factor-7 gene. Activation by interferon snd silencing by hypermethylation. J Biol Chem 275:31805-31812.

Malik P, Krall WJ, Yu X-J, Zhou C, and Kohn DB (1995). Retroviral mediated gene expression in human myelomonocytic cells: A comparison of hematopoietic cell promoters to viral promoters. Blood 86:2993-3005.

Marti HH, Wenger RH, Rivas LA, Straumann U, Digicaylioglu M, Henn V, Yonekawa Y, Bauer C, and Gassmann M (1996). Erythropoietin gene expression in human, monkey and murine brain. Eur J Neurosci 8:666-676.
Moreau-Gaudry F, Xia P, Jiang G, Perelman NP, Bauer G, Ellis J, Surinya KH, Mavilio F, Shen CK, and Malik P (2001). High-level erythroid-specific gene expression in primary human and murine hematopoietic cells with self-inactivating lentiviral vectors. Blood 98:2664-2672.

Murphy GP, Mirand EA, and Staubitz WJ (1976). The value of erythropoietin assay in the follow-up of Wilms' tumor patients. Oncology 33:154-156.

Nagai A, Nakagawa E, Choi HB, Hatori K, Kobayashi S, and Kim SU (2001). Erythropoietin and erythropoietin receptors in human CNS neurons, astrocytes, microglia, and oligodendrocytes grown in culture. J Neuropathol Exp Neurol 60:386392.

Nitta K, Uchida K, Kimata N, Honda K, Kobayashi H, Kawashima A, Yumura W, and Nihei H (1999). Recombinant human erythropoietin stimulates vascular endothelial growth factor release by glomerular endothelial cells. Eur J Pharmacol 373:121-124.

Ogilvie M, Yu X, Nicolas-Metral V, Pulido SM, Liu C, Ruegg UT, and Noguchi CT (2000). Erythropoietin stimulates proliferation and interferes with differentiation of myoblasts. J Biol Chem 275:39754-39761.

Perelman N, Selvaraj SK, Batra S, Luck LR, Erdreich-Epstien A, Coates TD, Kalra VK, and Malik P (2003). Placenta growth factor is increased in sickle cell disease, activates monocytes and modulates the clinical severity of sickle cell disease. Blood 102:1506-1514.

Ribatti D (2002). A potential role of erythropoietin in angiogenesis associated with myelodysplastic syndromes. Leukemia 16:1890.

Ribatti D, Presta M, Vacca A, Ria R, Giuliani R, Dell'Era P, Nico B, Roncali L, and Dammacco F (1999). Human erythropoietin induces a pro-angiogenic phenotype in cultured endothelial cells and stimulates neovascularization in vivo. Blood 93:2627-2636.

Sakisaka S, Watanabe M, Tateishi H, Harada M, Shakado S, Mimura Y, Gondo K, Yoshitake M, Noguchi K, Hino T, et al (1993). Erythropoietin production in hepatocellular carcinoma cells associated with polycythemia: immunohistochemical evidence. Hepatology 18:1357-1362.

Semenza GL (2002). Involvement of hypoxia-inducible factor 1 in human cancer. Intern Med 41:79-83.

Shimonaka M and Yamaguchi $Y$ (1994). Purification and biological characterization of epitaxin: A fibroblast-derived motility factor for epithelial cells. J Biol Chem 269:1428414289.

Spivak JL, Ferris DK, Fisher J, Noga SJ, Isaacs M, Connor E, and Hankins WD (1996). Cell cycle-specific behavior of erythropoietin. Exp Hematol 24:141-150.

Stolze I, Berchner-Pfannschmidt U, Freitag P, Wotzlaw C, Rossler J, Frede S, Acker H, and Fandrey J (2002). Hypoxiainducible erythropoietin gene expression in human neuroblastoma cells. Blood 100:2623-2628.

Sugawa M, Sakurai $Y$, Ishikawa-leda $Y$, Suzuki $H$, and Asou $H$ (2002). Effects of erythropoietin on glial cell development: Oligodendrocyte maturation and astrocyte proliferation. Neurosci Res 44:391-403.

Suzuki N, Ohneda O, Takahashi S, Higuchi M, Mukai HY, Nakahata T, Imagawa S, and Yamamoto M (2002). Erythroidspecific expression of the erythropoietin receptor rescued its null mutant mice from lethality. Blood 100:2279-2288. 
Thurman WG, Grabstald H, and Lieberman PH (1966). Elevation of erythropoietin levels in association with Wilms' tumor. Arch Intern Med 117:280-283.

Vaupel P, Kelleher DK, and Hockel M (2001). Oxygen status of malignant tumors: Pathogenesis of hypoxia and significance for tumor therapy. Semin Oncol 28:29-35.

Yasuda Y, Masuda S, Chikuma M, Inoue K, Nagao M, and Sasaki R (1998). Estrogen-dependent production of erythropoietin in uterus and its implication in uterine angiogenesis. J Biol Chem 273:25381-25387.

Yasuda Y, Musha T, Tanaka H, Fujita Y, Fujita H, Utsumi H, Matsuo T, Masuda S, Nagao M, Sasaki R, and Nakamura $Y$ (2001). Inhibition of erythropoietin signalling destroys xenografts of ovarian and uterine cancers in nude mice. $\mathrm{Br} \mathrm{J}$ Cancer 84:836-843.
Yu X, Shacka JJ, Eells JB, Suarez-Quian C, Przygodzki RM, Beleslin-Cokic B, Lin CS, Nikodem VM, Hempstead B, Flanders KC, Costantini F, and Noguchi CT (2002). Erythropoietin receptor signalling is required for normal brain development. Development 129:505-516.

Zhu H and Bunn HF (2001). Signal transduction. How do cells sense oxygen? Science 292:449-451. 